\title{
Conspectus of Aquatic Macrophytic Flora of Jammu \& Kashmir State, India
}

\author{
Ayaz Bashir shah ${ }^{1 *}$, Zafar A Reshi ${ }^{2}$ and Manzoor A Shah ${ }^{3}$ \\ ${ }^{1,2,3}$ Department of Botany, University of Kashmir Srinagar-190006, Jammu \& Kashmir, India \\ *Corresponding Author: shahayaz88@gmail.com \\ Available online at: www.isroset.org \\ Received: 02/Jan/2019, Accepted: 06/Feb/2019, Online: 28/Feb/2019
}

\begin{abstract}
Keeping in view importance of macrophytic in aquatic ecosystems, we focused on the diversity of macrophytes in Jammu and Kashmir State, the part western Himalaya. A total of 234 macrophytic species were reported from all three regions of state after taken into consideration both primary and secondary sources. The emergent macrophytes had the highest diversity, followed by rooted floating leaf- type, submerged and free floating. The maximum numbers of macrophytic species were recorded in the Kashmir valley while as minimum of 41 species from the Ladakh region. The lakes which have been submitted to an increasing eutrophication for the past several years is overgrown mainly by the aggressive interlopers like Typha sp., Phragmites australis, Sparganium ramosum and Scirpus sp and some free floating species.
\end{abstract}

Keywords: Macrophytes, emergent, submerged, eutrophication.

\section{INTRODUCTION}

The term 'aquatic macrophytes' refers to a diverse group of aquatic photosynthetic organisms which are large enough to be visible by the naked eye. They share a common feature of inhabiting an aquatic environment; growing either permanently submerged or rooted in at least temporarily inundated areas. Aquatic flora is spatially strongly variable with various abiotic and biotic actors of the environment (1). The main local determinants of the composition of aquatic flora are water level fluctuation (2), exposure $(3,4, \& 5)$, substrate composition and organic matter content (6), the amount of light (7), and water chemistry $(8,9)$.

Aquatic macrophytes play a vital role in healthy ecosystems. They serve as primary producers of oxygen through photosynthesis, provide a substrate for algae and shelter for many invertebrates, aid in nutrient cycling to and from the sediments, and help stabilize river and stream banks. Aquatic macrophytes also respond to the changes in water quality and have been used as indicator of pollution in several cases (10, 11). The role of macrophytes in freshwater aquatic systems has received increased attention over the last more than a decade, primarily due to their widespread decline in many lakes as a result of growing cultural eutrophication (12). Macrophytes are excellent indicators of lake condition for many reasons including their relatively high levels of species richness, rapid growth rates, and direct response to environmental change. Individual species show differential tolerance to a wide array of stressors. Thus, as environmental conditions vary, community composition respond through different shifting patterns. The composition of plant community can thus reflect, often with great sensitivity, the biological integrity of the aquatic ecosystems. The appreciation of the positive ecological values of macrophytes has led to a better understanding of their diversity and role in natural ecosystem for their scientific management.

Jammu and Kashmir State, part of northern India, represents the Trans-Himalayan zone and abounds in diverse aquatic ecosystems. Hitherto various studies pertaining to macrophytes have been undertaken, some of the significant earlier contributions to the macrophytic studies of Jammu and Kashmir lakes and wetlands include: $(13,14,15,16,17,18$, $19,20,21,22,23)$. However, no effort has been made to provide a checklist of macrophytic species of Jammu and Kashmir State as a whole. Keeping in view the importance of macrophytes in aquatic ecosystems and their management implications, the aim of the present work was to provide an authenticated checklist of macrophytic species of Jammu and Kashmir.

\section{MATERIALS AND METHODS}

\section{Study Area}

Jammu and Kashmir is a state in northern India, often denoted by its acronym, $\mathrm{J} \& \mathrm{~K}$. It is located mostly in the Himalayan mountains, and shares borders with the states of Himachal Pradesh and Punjab to the south. The 
biodiversity of the rich area of J\&K happens to be one of the hotspots in India with high endemicity. The whole Himalayan belt is one of the hotspot mega centre having 8 critical areas which includes two regions from the state viz Ladakh and Kashmir. Jammu and Kashmir is not a homogeneous land and the controlling factor of the climate is the Himalayas. It is marked by undulating topography and varied soil types that lead to the growth of diverse plants. The northern frontier of the state is fortified with the majestic mountains of the Himalaya Range. These ranges and their snowcapped peaks complete a picturesque landscape that includes crystal clear streams and lush green vegetation. Except the dry plateaus of Ladakh, the state receives ample amounts of rainfall. Winter season sees extensive precipitation in terms of snowfall. In the winter, the snow resembles a vast sheet of white blanket covering the valleys.

\section{DATA COLLECTION}

In Jammu and Kashmir state the region-wise macrophytic species occurrence data was collected from standard published literature sources including journals, books, reports from various governmental and non-governmental agencies ( $24,25,26,27,28,29,30,31,17,32$ ) and herbarium specimen. In addition, field surveys were carried out in some parts to crosscheck the already recorded species. The target species were later on grouped into different life forms and respective proportion of each life form in the aquatic species pool of the state was estimated.

\section{RESULT AND DISCUSSION}

Jammu and Kashmir State abounds in enchanting diversity of aquatic ecosystems, including wetlands, lakes, rivers, springs, streams. These ecosystems not only vary from alpine lakes to subalpine and temperate ones but also vary in characteristics in subtropical Jammu, Mediterranean Kashmir and cold arid Ladakh regions. These systems also present a gradient of trophic status ranging from some highly eutrophic through mesotrophic to some oligotrohic systems. Overall, these biodiversity rich aquatic ecosystems support a multitude of aquatic species. The high altitude lakes situated above 4,000 $\mathrm{m}$ are devoid of macrophytic vegetation, whereas the Kashmir valley aquatic systems (for instance, Anchar Lake, Dal Lake, Hokarsar, Wular Lake and Manasbal Lake etc.) have well stratified vegetation. There is a typical zonation pattern of plants discernible in aquatic systems of Kashmir Himalaya. The innermost zone has submerged plants, which have their flowers and fruits above the water surface. In the shallower water zone there are plants that have their leaves floating on the surface of water. Along the lake margins, the plants stand in water with the greater portion of the plants being visible above water. Small free-floating plants occur in the shallow waters and along lake margins.
During the present study a total of 234 macrophytic species belonging to 50 families (Table1) were recorded. Most dominant families in terms of species richness are Cyperaceae (53 spp.), Polygonaceae (15 spp.), Potamogetonaceae (14) and Poaceae (12). At regional scale, the highest number of species were reported in Kashmir (163 spp.) followed by Jammu (72 spp.) and Ladakh (41 spp.) (Fig.1).

The macrophytic vegetation in the aquatic ecosystems can be classified into four distinct groups: emergent, rooted-floating type, free floating leaf type and submerged.

\section{(i) Emergents}

The whole littoral region of the aquatic ecosystems is fringed with diverse emergent macrophytes. The emergent community was represented by 176 species, out of which highest number was recorded in Kashmir (116 spp.) and lowest in Ladakh (Fig. 2).

\section{(ii) Rooted floating-leaf type}

The shallow waters of the aquatic ecosystems are dominated by rooted floating leaf type community represented by 26 species. Highest number was reported in Kashmir followed by Jammu and Ladakh (Fig. 2). The species namely Potamogeton pectinatus L. was reported from all three regions of the state.

\section{(iii) Free floating type}

The distribution pattern of free-floating types of macrophytes is mainly determined by hydrological fluctuations and patterns of water flow. This type of aquatic flora form thick, mat-like scum, which dominate the side channels of the aquatic ecosystems rich in organic matter. The free floating community was represented by 11 species, out which 9 species were reported from Kashmir valley, 4 from Jammu region and none among them was reported from Ladakh (Fig. 2).

\section{(iv) Submerged}

The submerged species remain well under surface and this macrophytic community was represented by a total of 21 species. In Kashmir it is represented by 19 species while as in Jammu only 11 species were reported (Fig. 2).

\section{Discussion}

The overriding influence of cultural eutrophication on aquatic ecosystems of Jammu and Kashmir State has contributed significantly to nutrient loading and sedimentation rate. In spite of the tremendous ecological and socio-economic importance, the anthropogenic pressure on aquatic ecosystems seems to increase, especially in the Himalayan 
state of Jammu and Kashmir. Moreover due to rapid economic growth coupled with industrial revolution has not only increased water demand but has also led to disturbances in hydrological balances in catchment areas. As a matter of fact, wide spread pollution practices has degraded the water quality of these important systems. This in turn has induced a series of changes in vegetation and such changes have been well documented for aquatic ecosystems from the other region as well $(33,34)$. Excessive nutrient loadings can affect the plant communities in a variety of ways, shifting the species composition away from species that take up nutrients slowly, to those that are able to exploit nutrient pulses more rapidly or which have high nutrient requirements (35). The present investigation revealed that emergent species have become quite dominant over time and the overgrowth of this growth form at the cost of others almost across regions can be linked to eutrophication as shown by Makela et al. (36). Nutrient enrichment often results in growth of species tolerant to high nutrient loadings e.g. Typha and Phragmites (37). Later invasive plants, especially non-native invaders, such as Azolla, usually form a solid cover which creates compact, thick, floating mats, that shade the water column below them, restricting the submerged growth forms and thus altering the system dynamics altogether.

Aquatic plants and their communities are an important component of the littoral zone in various types of lakes. They form spatial characteristic patterns $(7,38)$ which often constitute a transitional boundary between open water and reed swamp communities. Macrophytes are involved in several feedback mechanisms that tend to keep the water clear even in relatively high nutrient loadings (39). Moreover macrophytes have been reported to affect the lake nutrient status, re-suspension of bottom materials and water turbidity (40, 41, \& 42). Aquatic plants and their communities may furthermore be good indicators of the changes occurring in lakes because of human induced acidification and eutrophication $(43,44)$. Macrophytes constitute an important component of wetland ecosystems which sustains a number of food chains in the water body. Though the aquatic ecosystems of Jammu and Kashmir state were evaluated for limnology and anthropogenic effect $(45,23 \& 46)$ yet very little information is available till date on the quantitative analysis of aquatic ecosystems which have utmost importance in management perspective and demands a due attention.

\section{CONCLUSIONS AND FUTURE DIRECTIONS}

The conspectus of macrophytic diversity in Jammu and Kashmir State, developed through primary and secondary sources, includes about 234 species in all the three regions of state. The database can potentially act as a basic corner stone for subsequent research on other vital aspects of aquatic ecosystems in the Kashmir Himalaya, a part of the world where such studies often take a back seat to other priorities. The macrophytic diversity as depicted from the present investigation still seems an underestimate because quite a large number of aquatic ecosystems across the three regions of Jammu, Kashmir and Ladakh are yet to be explored. Furthermore, there seem some taxonomic inflation also and the reported diversity of species also needs to be well characterized on various grounds for clear taxonomic status. An important challenge would be to monitor the impact of various anthropogenic pressures, land-use changes and climate change on the diversity and distribution of macrophytes.

\section{REFERENCES}

[1] Lacoul, P and Freedman, B (2006). Environmental influences on aquatic plants in freshwater ecosystems. Environmental Reviews, 14: 89-136.

[2] Rorslett, B (1989). An integrated approach to hydropower impact assessment. Hydrobiologia, 175: 65-82.

[3] Keddy, PA (1983). Shoreline Vegetation in Axe Lake, Ontario: Effects of Exposure on Zonation Patterns. Ecology, 64: 331-344.

[4] Weisner, S (1991). Within-lake patterns in depth penetration of emergent vegetation. Freshwat. Biol., 26: 133-142.

[5] Riis, T and Hawes, I. (2003). Effect of wave exposure on vegetation abundance, richness and depth distribution of shallow water plants in a New Zealand lake. Freshwat. Biol., 48: 75-87.

[6] Barko, JW and Smart, RM (1986). Sediment related mechanisms of growth limitations in submersed macrophytes. Ecology, 67 (5): 1328-1340.

[7] Spence, DHN (1982). The zonation of plants in fresh-water lakes. Adv. Ecol. Res., 12: 37-125.

[8] Toivonen, H and Huttunen, P (1995). Aquatic macrophytes and ecological gradients in 57 small lakes in southern Finland. Aquat. Bot., 51: 197-221.

[9] Jeppesen, E., Jensen, JP., Soendergaard, M., Lauridsen, T and Landkildehus, F (2000). Trophic structure, species richness and biodiversity in Danish lakes: changes along a phosphorus gradient. Freshwat. Biol., 45: 201-218.

[10] Ramakrishnan, N (2003).Bio-monitoring approaches for water quality assessment in two Waterbodies At tiruvannamalai, tamil nadu india, Proceedings of the Third International Conference on Environment and Health, Chennai, India, $374-385$.

[11] Palit, D and Mukharjee, A (2012). Studies on water quality and macrophytes composition in wetlands of Bankura district, West Bengal, India. Ind. J. Plant Sci., (2\&3): 221-228.

[12] Egertson, CJ, Kopaska, JA and Downing, JA (2004). A century of change in macrophyte abundance and composition in response to agricultural eutrophication. Hydrobiologia 524: 145-156.

[13] Mukherjee, SK (1921). The Dal Lake: A study in biotic succession. Proc. Indian Sci. Cong., 8:185.

[14] Kaul, V and Zutshi, DP (1967). A study of aquatic and marshland vegetation of Srinagar lakes. Proc. Nat. Inst. Sci. India, 3313: 111128.

[15] Zutshi, DP (1968). Ecology of some Kashmir Lakes. Ph. D. Thesis J\&K Univ., Srinagar.

[16] Kak, AM (1978). Taxanomic studies of aquatic angiosperms of Kashmir. Ph. D. Thesis, Kashmir University. Srinagar.

[17] Kak, AM (1990). Aquatic and wetland vegetation of Kashmir Himalaya. Journal of Economic, Taxonomic Botany, 4: 1-14.

[18] Pandit, AK (1984). Role of macrophytes in aquatic ecosystems and management of freshwater resources. J. Environ. Manage., 18: 7388.

[19] Pandit, AK (1999). Freshwater Ecosystems of the Himalaya. Parthenon Publications, New York, London. 
[20] Pandit, AK (2001). Plant diversity in freshwater ecosystems of north-west Himalaya. Journal of Research and Development, 1: 121.

[21] Pandit, AK and Qadri, (1990). Floods threatening Kashmir wetlands. J. Environ Manage., 31:299-311.

[22] Gangoo, SA and Makaya, AS (2000). Changes in vegetation pattern of Hokersar (wetland reserve), Kashmir. pp 107-112. In: Environmental Biodiversity and conservation. Khan, ed) A.P.H. publishing House, New Delhi. India.

[23] Rather, GH and Pandit, AK (2005). Diversity of emergent macrophytes in two rural valley lakes of Kashmir Himalaya. Journal of Research \& Development, 5:71-77.

[24] Cook, CDK (1996). Aquatic and wetland plants of India. Oxford university press. New York

[25] Kala, PC and Mathur VB (2002). Patterns of plant species distribution in the Trans-Himalayan region of Ladakh, India. Journal of Vegetation Science, 13: 751-754.

[26] Klimes, L and Dickoré, B (2005). A contribution to the vascular plant flora of Lower Ladakh (Jammu \& Kashmir, India). Willdenowia, 35.

[27] Sekar, KC (2012). Invasive Alien Plants of Indian Himalayan Region- Diversity and Implication. American Journal of Plant Sciences, 3: 177-184.

[28] Shah, AB., Reshi, ZA and Shah, MA (2014). Clonal trait diversity in aquatic angiosperms of Kashmir Valley, India. MPhil. Dissertation, University of Kashmir, Srinagar.

[29] Kour, R., Kaur, B., Bhatia, S and Sharma, KK (2014). Documentation of Aquatic Invasive Alien flora of Jammu region, Jammu and Kashmir. International Journal of Interdisciplinary and Multidisciplinary Studies (IJIMS), Vol 1, 7: 90-96.

[30] Kak, AM (1981). Aquatic and wetland flora of the Northwestern Himalayas- XII.Aquatic Ranunculaceae. Biol. Bull. India, 3(3): 146-159.

[31] Kak, AM (1982). Aquatic and wetland flora of the Northwestern Himalayas-XVII. Family Botumaceae in the Kashmir Himalayas.Biol. Bull. India, 4(3): 197-198.

[32] Anand, VK and Sharma, S (1991). Studies on the macrophytic vegetation of lake Mansar( Jammu), J. Phytol. Res., 4(1): 67-72.

[33] Ozimek, T (1978). Effects of municipal sewage on the submerged macrophytes of a lake littoral. Ekol. Pol., 26: 3-39.

[34] Heino, J., Virkkala, R and Toivonen, H (2009). Climate change and freshwater biodiversity: detected patterns, future trends and adaptations in northern regions. Biological Reviews, 84: 39-54.
[35] Wetzel, PR and van der Valk, AG (1998). Effects of nutrient and soil moisture on competition between Carex stricta, Phalaris arundinacea and Typha latifolia. Plant Ecology, 138: 179-190.

[36] Makela, S., Haitu, E and Arvola, L (2004). Spatial patterns in aquatic vegetation composition and environmental covariates along chains of lakes in Kokemaenjoki watershed (S. Finland). Aquatic Botany, 80: 253-269.

[37] Galatowitsch, SM., Anderson, NO and Ascher, PD (1999). Invasiveness in wetland plants in temperate North America. Wetlands, 19: 733-755.

[38] Klosowski, S (1992). Ekologia I warstosc wskaznikowa zbiorowisk roslonnosci szuwarowej naturalnych zbiornikow wod stojacych [The ecology and indicative value of the swamp communities of the natural reservoirs of stagnated water]. Fragmenta Floristica et Geobotanica, 37: 563-595.

[39] Moss, B (1990). Engineering and biological approaches to the restoration from eutrophication of shallow lakes in which aquatic plant communities are important components. Hydrobiologia, 61: 367-378.

[40] James, WF and Barko, JW (1990). Macrophyte influences on the zonation of sediment accretion and composition in a north temperate reservoir. Archiv für Hydrobiologie, 120: 129-142.

[41] Sand-Jensen, K and Borum, J (1991). Interactions among phytoplankton, periphyton and macrophytes in temperate freshwaters and estuaries. Aquatic Botany, 41: 137-175.

[42] Horppila, J and Nurminen, L (2001). The effect of emergent macrophyte (Typha angustifolia) on sediment resuspension in a shallow north temperate lake. Freshwater Biology, 46: 1447-1455.

[43] Roelofs, JGM (1983). Impact of acidification and eutrophication on macrophyte communities in soft waters in Netherlands I. Field Observations. Aquatic Botany, 17: 139-155.

[44] Lehman, A and Lachavanne, JB (1999). Changes in water quality of Lake Geneva indicated by submerged macrophytes. Freshwater Biology, 42: 457-466.

[45] Khan, MA and Shah, MA (2004). The environmental status of a Kashmir Himalayan wetland game reserve: Aquatic plant communities. Lakes and Reservoirs: Research and Management, 9: 125-132.

[46] Parray, S., Alam, A., Nigam, G and Shah, MA (2009). Land use pattern in the catchment and its impact on the ecology of suburban wetland (Chatlam) Kashmir Himalaya. Indian Journal of Applied \& Pure Biology, 24: 521-527.

\section{Figures:}

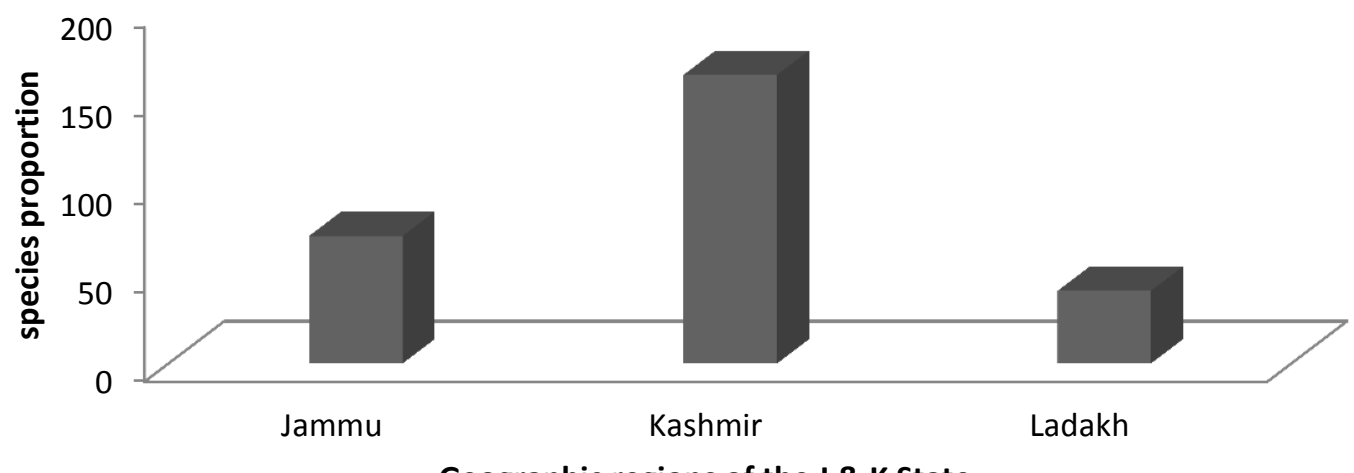

Fig.1: Proportion of macrphytic species in three different regions of state. 


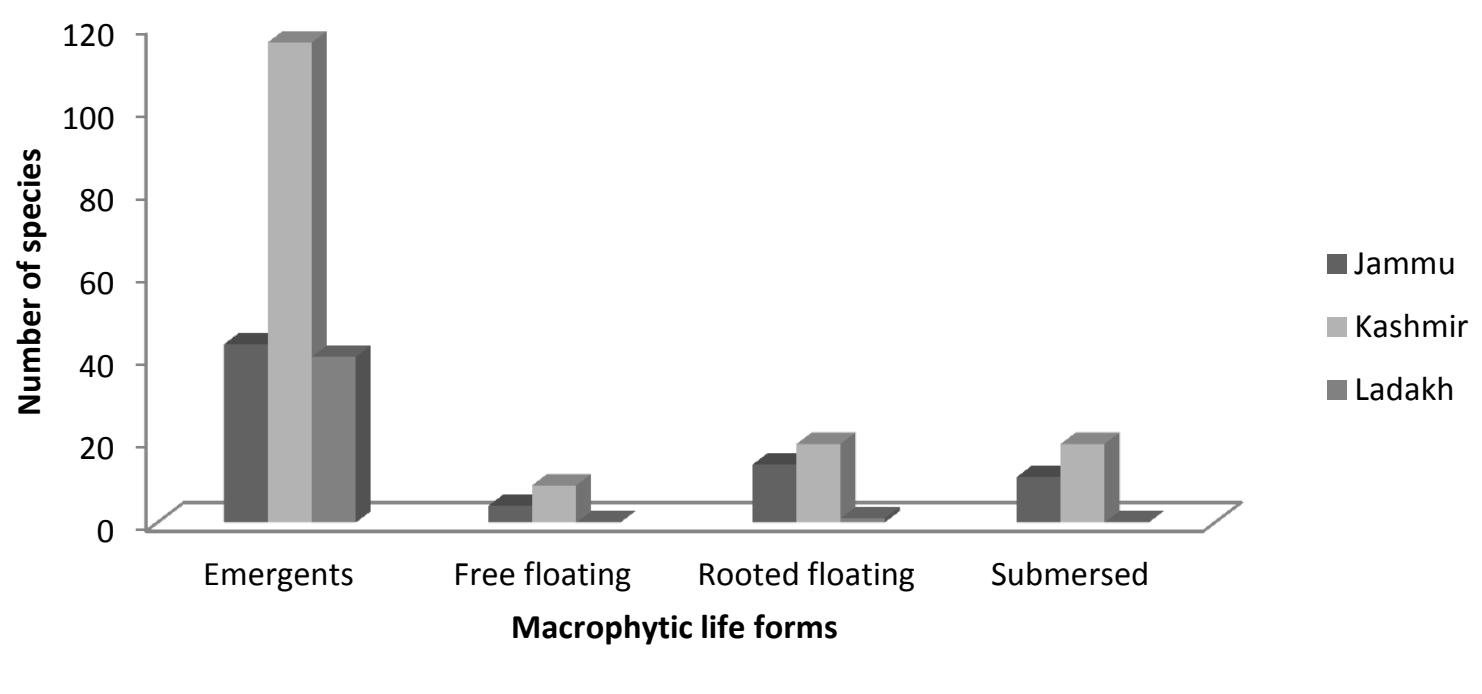

Fig. 2: Species proportion in different life forms of aquatic macrophytes.

Table 1: Checklist of macrophytic species from Jammu, Kashmir and Ladakh regions of the Jammu and Kashmir State.

\begin{tabular}{|c|c|c|c|c|}
\hline \multirow[t]{2}{*}{ Family/plant species } & \multirow[t]{2}{*}{$\begin{array}{c}\text { Growth } \\
\text { Form } \\
\end{array}$} & \multicolumn{3}{|c|}{$\begin{array}{l}\text { Presence /Absence data of aquatic } \\
\text { macrphytes }\end{array}$} \\
\hline & & Jammu & Kashmir & Ladakh \\
\hline \multicolumn{5}{|l|}{ Alismataceae } \\
\hline Alisma gramineum Lej. & $\mathrm{E}$ & - & + & - \\
\hline Alisma lanceolatum With. & $\mathrm{E}$ & - & + & - \\
\hline Alisma plantago-aquatica $\mathrm{L}$. & $\mathrm{E}$ & + & + & - \\
\hline Caldesia parnassifolia (L.) Parl & $\mathrm{E}$ & + & - & - \\
\hline Saggitaria latifolia Willd. & $\mathrm{E}$ & - & + & - \\
\hline Saggitaria sagittifolia L. & $\mathrm{E}$ & - & + & - \\
\hline Sagittaria subulata (L.) Buchenau & RF & + & - & - \\
\hline \multicolumn{5}{|l|}{ Amaranthaceae } \\
\hline Amaranthus lividus L. & $\mathrm{E}$ & - & + & - \\
\hline Alternanthera philoxeroides Griseb. & $\mathrm{E}$ & + & - & - \\
\hline Alternanthera sessilis (L.) R. Br. ex DC. & $\mathrm{E}$ & + & + & - \\
\hline Alternanthera caracasana Kuwth. & $\mathrm{E}$ & - & + & - \\
\hline \multicolumn{5}{|l|}{ Apiaceae } \\
\hline Berula erecta (Huds.) Coville & $\mathrm{E}$ & - & + & - \\
\hline Oenanthe crocata $\mathrm{L}$. & $\mathrm{E}$ & + & - & - \\
\hline Sium latijugum C.B. Clarke & $\mathrm{E}$ & - & + & - \\
\hline \multicolumn{5}{|l|}{ Araceae } \\
\hline Acorus calamus L. & $\mathrm{E}$ & + & + & - \\
\hline \multicolumn{5}{|l|}{ Asteraceae } \\
\hline Artimisia spp. & $\mathrm{E}$ & + & - & - \\
\hline Bidens cirnua $\mathrm{L}$. & $\mathrm{E}$ & - & + & - \\
\hline Bidens tripartita L. & $\mathrm{E}$ & - & + & - \\
\hline Eclipta prostrata (Linn.) Mant. & $\mathrm{E}$ & - & + & - \\
\hline Azollaceae & & & & \\
\hline
\end{tabular}




\begin{tabular}{|c|c|c|c|c|}
\hline Azolla cristata Kaulf. & $\mathrm{FF}$ & - & + & - \\
\hline Azolla pinnata $\mathrm{R} . \mathrm{Br}$. & $\mathrm{FF}$ & + & - & - \\
\hline \multicolumn{5}{|l|}{ Balsaminaceae } \\
\hline Impatiens glandulifera Royle & $\mathrm{E}$ & - & + & - \\
\hline Impatiens thomsonii Hook. f. & $\mathrm{E}$ & - & - & + \\
\hline \multicolumn{5}{|l|}{ Boraginaceae } \\
\hline Myosotis scorpioides L. & $\mathrm{E}$ & - & + & - \\
\hline Myosotis caespitosa Schultz & $\mathrm{E}$ & - & + & - \\
\hline Myosotis palustris (Linn.) Nath & $\mathrm{E}$ & - & + & - \\
\hline \multicolumn{5}{|l|}{ Brassicaceae } \\
\hline Barbarea intermedia Boreau & $\mathrm{E}$ & - & + & - \\
\hline Barbarea vulgaris W. T. Aiton & $\mathrm{E}$ & - & + & - \\
\hline Cardamine flexuosa With & $\mathrm{E}$ & - & + & - \\
\hline Cardamine hirsuta $\mathrm{L}$ & $\mathrm{E}$ & + & + & - \\
\hline Nasturtium officinale W. T. Aiton & $\mathrm{E}$ & + & + & - \\
\hline Rorippa islandica (Oeder) Borbás & $\mathrm{E}$ & - & + & - \\
\hline \multicolumn{5}{|l|}{ Butomaceae } \\
\hline Butomus umbellatus L. & $\mathrm{E}$ & - & + & - \\
\hline \multicolumn{5}{|l|}{ Cabombaceae } \\
\hline Cabomba caroliniana A. Gray & RF & + & - & - \\
\hline \multicolumn{5}{|l|}{ Callitrichaceae } \\
\hline Callitriche stagnalis Scop & $\mathrm{E}$ & - & + & - \\
\hline C. palustris Linn. & $\mathrm{E}$ & - & + & - \\
\hline C.truncata Guss. & $\mathrm{E}$ & - & + & - \\
\hline \multicolumn{5}{|l|}{ Caryophyllaceae } \\
\hline Myosoton aquaticum (L.) Moench & $\mathrm{E}$ & - & + & - \\
\hline \multicolumn{5}{|l|}{ Ceratophyllaceae } \\
\hline Ceratophyllum demersum L. & $\mathrm{S}$ & + & + & - \\
\hline Ceratophyllum submersum L. & $\mathrm{S}$ & + & - & - \\
\hline \multicolumn{5}{|l|}{ Convolvulaceae } \\
\hline Ipomoea carnea Jace. & $\mathrm{E}$ & + & - & - \\
\hline I. aquatic Forssk. & $\mathrm{E}$ & + & - & - \\
\hline \multicolumn{5}{|l|}{ Cyperaceae } \\
\hline Ascolepsis spp. & $\mathrm{E}$ & + & - & - \\
\hline Blysmus compressus (L.) Panz. ex Link & $\mathrm{E}$ & - & - & + \\
\hline Carex diluta Bieb. & $\mathrm{E}$ & - & + & - \\
\hline C. fedia Nees & $\mathrm{E}$ & - & + & - \\
\hline C. foliosa D.Don & $\mathrm{E}$ & - & + & - \\
\hline C.gilessi Nelmes & $\mathrm{E}$ & - & + & - \\
\hline Carex microglochin Wahlenb. & $\mathrm{E}$ & - & - & + \\
\hline C. nubigena D.Don & $\mathrm{E}$ & - & + & - \\
\hline C. orbicularis Boott & $\mathrm{E}$ & - & - & + \\
\hline C. pseudocyperus Linn. & $\mathrm{E}$ & - & + & - \\
\hline C. sagaensis Yen C. Yang & $\mathrm{E}$ & - & - & + \\
\hline C. stenophylla Wahlenb. & $\mathrm{E}$ & - & - & + \\
\hline C. distans L. & $\mathrm{E}$ & + & - & - \\
\hline Cladium mariscus (L.) Pohl & $\mathrm{E}$ & - & + & - \\
\hline Cyperus cyperoides (L.) O. Ktze. & $\mathrm{E}$ & - & + & - \\
\hline C. difformis L. & $\mathrm{E}$ & + & - & - \\
\hline C. fuscus L. & $\mathrm{E}$ & - & + & - \\
\hline C. globosus All. & $\mathrm{E}$ & - & + & - \\
\hline C. glomeratus Linn. & $\mathrm{E}$ & - & + & - \\
\hline C. iria L. & $\mathrm{E}$ & + & + & - \\
\hline C. michelianus (L.)Link & $\mathrm{E}$ & - & + & - \\
\hline C. pygmaeus Rottb. & $\mathrm{E}$ & - & + & - \\
\hline
\end{tabular}




\begin{tabular}{|c|c|c|c|c|}
\hline C. pumilus Linn. & $\mathrm{E}$ & - & + & - \\
\hline C. rotundus L. & $\mathrm{E}$ & - & + & - \\
\hline C. sanguinolentus Linn. & $\mathrm{E}$ & - & + & - \\
\hline C. serotinus Rottb. & $\mathrm{E}$ & - & + & - \\
\hline Cyperus squarrosus L. & $\mathrm{E}$ & - & - & + \\
\hline Cyperus tenuispica Steud. & $\mathrm{E}$ & + & - & - \\
\hline Eleocharis acicularis (L.) Roem. \& Schult. & $\mathrm{E}$ & - & + & - \\
\hline E. atropurpurea (Retz.) Kunth & $\mathrm{E}$ & - & + & - \\
\hline E. obscura T. Koyama & $\mathrm{E}$ & - & + & - \\
\hline E. palustris (L.) Roem. \& Schult. & $\mathrm{E}$ & - & + & - \\
\hline E. parishii Britton & $\mathrm{E}$ & - & + & - \\
\hline E. pauciflora Link. & $\mathrm{E}$ & - & + & - \\
\hline E. uniglumis (Link)Schult. & $\mathrm{E}$ & - & + & - \\
\hline Eleocharis quinqueflora (Hartmann) O. Schwarz & $\mathrm{E}$ & - & - & + \\
\hline E.plantagineum L. & $\mathrm{E}$ & + & - & - \\
\hline Fimbristylis dichotoma (L.) Vahl. & $\mathrm{E}$ & - & + & - \\
\hline F. miliacea (Linn.)Vahl. & $\mathrm{E}$ & - & + & - \\
\hline F. squarrosa Vahl. & $\mathrm{E}$ & - & + & - \\
\hline Isolepis setacea (L.) R. Br. & $\mathrm{E}$ & - & - & + \\
\hline Kobresia schoenoides (C. A. Mey.) Steud. & $\mathrm{E}$ & - & - & + \\
\hline Scirpus acutus Muhl. Ex Bigelow & $\mathrm{E}$ & + & - & - \\
\hline S. articulates $\mathrm{L}$. & $\mathrm{E}$ & + & - & - \\
\hline S. juncoides Roxb. & $\mathrm{E}$ & - & + & - \\
\hline S. lacustris Linn. & $\mathrm{E}$ & - & + & - \\
\hline S. lateriflous Gmel. & $\mathrm{E}$ & - & + & - \\
\hline S. martimus L. & $\mathrm{E}$ & - & + & - \\
\hline S. mucronatas & $\mathrm{E}$ & + & - & - \\
\hline S. setaceus Linn. & $\mathrm{E}$ & - & + & - \\
\hline S. subterminalis Torr. & $\mathrm{E}$ & + & - & - \\
\hline S. triqueter $\mathrm{L}$. & $\mathrm{E}$ & - & + & - \\
\hline S. validus & $\mathrm{E}$ & + & - & - \\
\hline \multicolumn{5}{|l|}{ Elatinaceae } \\
\hline Elatine triandra Schkuhr & $\mathrm{S}$ & - & + & - \\
\hline \multicolumn{5}{|l|}{ Eriocaulaceae } \\
\hline Eriocaulon sieboldianum Sieb. & $\mathrm{E}$ & - & + & - \\
\hline \multicolumn{5}{|l|}{ Haloragaceae } \\
\hline Myriophyllum verticillatum L. & $\mathrm{E}$ & - & + & - \\
\hline Myriophyllum spicatum L. & $\mathrm{S}$ & + & + & - \\
\hline Myriophyllum aquaticum (Vell.) Verdc. & $\mathrm{E}$ & - & + & - \\
\hline \multicolumn{5}{|l|}{ Hippuridaceae } \\
\hline Hippuris vulgaris L. & $\mathrm{E}$ & - & + & - \\
\hline \multicolumn{5}{|l|}{ Hydrocharitaceae } \\
\hline Hydrilla verticillata (L.f.) Royle & $\mathrm{S}$ & + & + & - \\
\hline Hydrocharis dubia (Blume) Backer & RF & - & + & - \\
\hline Vallisenaria americana Michx. & RF & + & - & - \\
\hline Vallisneria spiralis L. & RF & + & + & - \\
\hline Elodea canadensis Rich. & RF & + & - & - \\
\hline Egeria densa Vict. & RF & + & - & - \\
\hline \multicolumn{5}{|l|}{ Isoetaceae } \\
\hline Isoetes lacustris L. & $\mathrm{E}$ & + & - & - \\
\hline \multicolumn{5}{|l|}{ Juncaceae } \\
\hline Juncus articulatus L. & $\mathrm{E}$ & - & - & + \\
\hline Juncus aquatic L. & $\mathrm{E}$ & + & + & - \\
\hline Juncus bufonius L. & $\mathrm{E}$ & - & + & + \\
\hline Juncus himalensis Klotzsch & $\mathrm{E}$ & - & - & + \\
\hline
\end{tabular}




\begin{tabular}{|c|c|c|c|c|}
\hline Juncus inflexus L. & $\mathrm{E}$ & - & + & - \\
\hline Juncus membranaceus Royle ex D. Don & $\mathrm{E}$ & - & - & + \\
\hline Juncus thomsonii Buchenau & $\mathrm{E}$ & - & - & + \\
\hline Juncus turkestanicus V. Krecz. \& Gontsch & $\mathrm{E}$ & - & - & + \\
\hline \multicolumn{5}{|l|}{ Juncaginaceae } \\
\hline Triglochin palustris Linn. & $\mathrm{E}$ & - & + & + \\
\hline \multicolumn{5}{|l|}{ Labiatae (Lamiaceae) } \\
\hline Lycopus europaeus L. & $\mathrm{E}$ & - & + & - \\
\hline Mentha aquatic L. & $\mathrm{E}$ & - & + & - \\
\hline Mentha arvensis L. & $\mathrm{E}$ & - & + & - \\
\hline Mentha longifolia (L.) Huds. & $\mathrm{E}$ & - & + & - \\
\hline Mentha piperita $\mathrm{L}$ & $\mathrm{E}$ & - & + & - \\
\hline Mentha spicata L. & $\mathrm{E}$ & - & + & - \\
\hline Mentha royleana Benth. & $\mathrm{E}$ & - & - & + \\
\hline \multicolumn{5}{|l|}{ Lemnaceae } \\
\hline Lemna gibba L. & FF & - & + & - \\
\hline Lemna minor L. & FF & + & + & - \\
\hline Lemna trisulca $\mathrm{L}$. & FF & - & + & - \\
\hline Lemna turionifera Landolt & FF & - & + & - \\
\hline Spirodela polyrhiza (L.) Schleid. & FF & + & + & - \\
\hline Wolffia arrhiza (L.) Horkel ex Wimm. & FF & - & + & - \\
\hline Wolffia trifoliate $\mathrm{H}$. Karst. & FF & - & + & - \\
\hline \multicolumn{5}{|l|}{ Lentibulariaceae } \\
\hline Utricularia aurea Lour. & $\mathrm{S}$ & - & + & - \\
\hline U. minor Linn. & $\mathrm{S}$ & - & + & - \\
\hline \multicolumn{5}{|l|}{ Lytharaceae } \\
\hline Ammania auriculata Willd. & $\mathrm{E}$ & - & + & - \\
\hline Ammania baccifera $\mathrm{L}$. & $\mathrm{E}$ & - & + & - \\
\hline Lythrum salicaria $\mathrm{L}$. & $\mathrm{E}$ & - & + & - \\
\hline Rotala densiflora (Willd.) Koehne & $\mathrm{E}$ & - & + & - \\
\hline \multicolumn{5}{|l|}{ Marsiliaceae } \\
\hline Marsilia quadrifolia $\mathrm{L}$. & $E$ & + & + & - \\
\hline \multicolumn{5}{|l|}{ Menyanthaceae } \\
\hline Menyanthes trifoliate $\mathrm{L}$. & $\mathrm{E}$ & - & + & - \\
\hline Nymphoides aquatic (J.F.Gmel.) Kuntze & RF & + & - & - \\
\hline Nymphoides indica (L.) Kuntze & RF & + & - & - \\
\hline N. Cristata (Roxb.) O. Ktze. & RF & + & - & - \\
\hline N. stellata Willd. & RF & + & - & - \\
\hline N. peltata (S.G.Gmel.) Kuntze & RF & - & + & - \\
\hline \multicolumn{5}{|l|}{ Najadaceae } \\
\hline Najas graminea Del. & $\mathrm{S}$ & + & + & - \\
\hline N. indica (Willd.) Cham. & $\mathrm{S}$ & + & - & - \\
\hline N. marina L. & $\mathrm{S}$ & - & + & - \\
\hline N. minor (Pers.) All. & $\mathrm{S}$ & + & + & - \\
\hline \multicolumn{5}{|l|}{ Nelumbonaceae } \\
\hline Nelumbo nucifera Gaertn. & RF & + & + & - \\
\hline \multicolumn{5}{|l|}{ Nymphaeceae } \\
\hline Eurayle ferox Salisb. & RF & - & + & - \\
\hline Nymphaea alba L. & RF & - & + & - \\
\hline N. candida C. Presl. & RF & - & + & - \\
\hline N.lotus L. & RF & - & + & - \\
\hline N. Mexicana Zucc. & RF & - & + & - \\
\hline N. stellate Willd. & RF & - & + & - \\
\hline N. tetragona Georgi. & RF & - & + & - \\
\hline \multicolumn{5}{|l|}{ Onagraceae } \\
\hline Epilobium cylindricum D. Don & $\mathrm{E}$ & + & + & + \\
\hline
\end{tabular}




\begin{tabular}{|c|c|c|c|c|}
\hline Epilobium glaciale P. H. Raven & $E$ & - & - & + \\
\hline Epilobium hirsutum (L) Gray & $\mathrm{E}$ & - & + & - \\
\hline E. parviflorum (Schreb.) DC. & $\mathrm{E}$ & - & + & - \\
\hline Epilobium palustre L. & $\mathrm{E}$ & - & + & - \\
\hline Epilobium royleanum Hausskn. & $\mathrm{E}$ & - & - & + \\
\hline Epilobium tibetanum Hausskn & $\mathrm{E}$ & - & - & + \\
\hline \multicolumn{5}{|l|}{ Orchidaceae } \\
\hline Spiranthes lancea (Thunb.) Baker & $\mathrm{E}$ & - & + & - \\
\hline \multicolumn{5}{|l|}{ Papilionaceae } \\
\hline Aeschynomene indica $\mathrm{L}$. & $E$ & + & - & - \\
\hline \multicolumn{5}{|l|}{ Poaceae } \\
\hline Agrostis gigantea Roth & $\mathrm{E}$ & - & - & + \\
\hline Arundo donax L. & $\mathrm{E}$ & + & - & - \\
\hline Echinochloa colonum (L.) Link. & $\mathrm{E}$ & - & + & - \\
\hline Echinochloa crus-galli (L.) P.Beauv. & $\mathrm{E}$ & - & + & - \\
\hline Hymenachne amplexicaulis (Rudge) Nees & $\mathrm{E}$ & + & - & - \\
\hline Paspalidium germinatum (Forssk.) Stapf & $\mathrm{E}$ & + & - & - \\
\hline Paspalum paspalodes (Michx.) Scribner & $\mathrm{E}$ & - & + & - \\
\hline Poa annua $\mathrm{L}$. & $\mathrm{E}$ & + & - & + \\
\hline Polypogon monspliensis (L.) Desf. & $\mathrm{E}$ & + & - & + \\
\hline Phalaris arundinacea $\mathrm{L}$. & $\mathrm{E}$ & - & + & - \\
\hline Phragmites australis (Cav.) Trin. Ex Steud. & $\mathrm{E}$ & - & + & + \\
\hline Hygrorhiza aristata & $\mathrm{E}$ & + & - & - \\
\hline \multicolumn{5}{|l|}{ Polygonaceae } \\
\hline Koenigia islandica L. & $\mathrm{E}$ & - & - & + \\
\hline Persicaria barbata (L.) H. Hara & $\mathrm{E}$ & + & - & - \\
\hline Persicaria flaccidum (L.) H. Hara & $\mathrm{E}$ & + & - & - \\
\hline Persicaria glabrum (Willd.) M. Gómez. & $\mathrm{E}$ & + & - & - \\
\hline Persicaria glacialis (Meissn.) Hara & $\mathrm{E}$ & - & - & + \\
\hline Persicaria hydropiper L. & $\mathrm{E}$ & - & + & + \\
\hline P. lapathifolia(Linn.) Gray ex Nakia & $E$ & - & + & + \\
\hline P. nepalense Meisn. & $\mathrm{E}$ & - & + & + \\
\hline P. punctate (Eliot) Smoel & $\mathrm{E}$ & - & + & - \\
\hline P. nodosa (Pers.) Opiz. & $\mathrm{E}$ & - & + & - \\
\hline Rumex aquaticus $\mathrm{L}$. & $\mathrm{E}$ & - & + & - \\
\hline Rumex chalepensis Mill & $\mathrm{E}$ & - & + & - \\
\hline Rumex conglomeratus Murray & $\mathrm{E}$ & - & + & - \\
\hline Rumex dentatus L. & $\mathrm{E}$ & - & + & - \\
\hline Rumex paulsenianus Rech. & $\mathrm{E}$ & - & + & - \\
\hline \multicolumn{5}{|l|}{ Pontederiaceae } \\
\hline Monochoria vaginalis (Burm. F)Presl. Ex Kunth & $\mathrm{E}$ & - & + & - \\
\hline Eichhornia crassipes (Mart.) Solms & $\mathrm{E}$ & + & - & - \\
\hline \multicolumn{5}{|l|}{ Potamogetonaceae } \\
\hline Potamogeton crispus L. & $\mathrm{S}$ & + & + & - \\
\hline Potamogeton filiformis Pers. & $\mathrm{S}$ & - & + & - \\
\hline Potamogeton fluitans Roth & RF & - & + & - \\
\hline Potamogeton natans L. & RF & + & + & - \\
\hline Potamogeton nodosus Poir. & RF & + & + & - \\
\hline Potamogeton lucens L. & $\mathrm{S}$ & + & + & - \\
\hline Potamogeton pectinatus L. & RF & + & + & + \\
\hline Potamogeton perfoliatus L. & $\mathrm{S}$ & + & + & - \\
\hline Potamogeton pusillus L. & $\mathrm{S}$ & + & + & - \\
\hline P. salicifolius Wolfg. ex Schult. \& Schult.f. & $\mathrm{S}$ & + & - & - \\
\hline Potamogeton wrightii Morang & $\mathrm{S}$ & - & + & - \\
\hline Potamogeton berchtoldii Fieber & $\mathrm{S}$ & - & + & - \\
\hline
\end{tabular}




\begin{tabular}{|c|c|c|c|c|}
\hline Potamogeton amblyphyllus C. A. Mey & $\mathrm{S}$ & - & + & - \\
\hline Potamogeton trichoides Cham. & $\mathrm{S}$ & - & + & - \\
\hline \multicolumn{5}{|l|}{ Portulaceae } \\
\hline Portula oleracea L. & RF & - & + & - \\
\hline \multicolumn{5}{|l|}{ Ranunculaceae } \\
\hline Anemone rivularis Buch. & $\mathrm{E}$ & - & - & + \\
\hline Halerpestes sarmentosa (Adams) Kom. \& Aliss. & $\mathrm{E}$ & - & - & + \\
\hline Ranunculus arvensis & $\mathrm{E}$ & + & - & - \\
\hline Ranunculus longicaulis C. A. Mey. & $\mathrm{E}$ & - & - & + \\
\hline Ranunculus muricatus L. & $\mathrm{E}$ & - & + & - \\
\hline Ranunculus sceleratus L. & $\mathrm{E}$ & + & + & - \\
\hline Caltha alba K. Jacq & $\mathrm{E}$ & - & + & - \\
\hline Rananculus lingua $L$. & $\mathrm{E}$ & - & + & - \\
\hline Ranunculus trichophyllus Chaix & RF & - & + & - \\
\hline \multicolumn{5}{|l|}{ Rosaceae } \\
\hline Potentilla anserina $\mathrm{L}$. & $\mathrm{E}$ & - & - & + \\
\hline Potentilla reptans Linn. & $\mathrm{E}$ & - & + & - \\
\hline \multicolumn{5}{|l|}{ Rubiaceae } \\
\hline Galium aparine $\mathrm{L}$. & $\mathrm{E}$ & - & + & - \\
\hline \multicolumn{5}{|l|}{ Salviniaceae } \\
\hline Salvinia molesta Mitchell & FF & + & - & - \\
\hline Salvinia natans All. & FF & - & + & - \\
\hline \multicolumn{5}{|l|}{ Scrophulariaceae } \\
\hline Bacopa monnieri (L.) Pennell & $\mathrm{E}$ & + & - & - \\
\hline $\begin{array}{l}\text { Pedicularis longiflora subsp. tubiformis (Klotzsch) } \\
\text { Pennell }\end{array}$ & $\mathrm{E}$ & - & - & + \\
\hline Pedicularis punctata Decne. & $\mathrm{E}$ & - & - & + \\
\hline Veronica anagallis-aquatica L. & $\mathrm{E}$ & + & + & - \\
\hline Veronica salina Schur & $\mathrm{E}$ & - & - & + \\
\hline Veronica beccabunga L. & $\mathrm{E}$ & - & + & + \\
\hline Limosella aquatica L. & $\mathrm{E}$ & - & + & - \\
\hline Limnophila spp. & $\mathrm{S}$ & + & - & - \\
\hline Sparginaceae & & - & - & - \\
\hline Sparganium erectum Huds & $\mathrm{E}$ & - & + & - \\
\hline \multicolumn{5}{|l|}{ Trapaceae } \\
\hline Trapa natans L. & RF & - & + & - \\
\hline \multicolumn{5}{|l|}{ Typhaceae } \\
\hline Typha angustata Bory \& Chaub. & $\mathrm{E}$ & + & + & + \\
\hline Typha laxmannii Lepech. & $\mathrm{E}$ & - & + & + \\
\hline \multicolumn{5}{|l|}{ Umbelliferae } \\
\hline $\begin{array}{c}\text { Seseli mucronatum (Schrenk) Pimenov \& } \\
\text { Sdobnina }\end{array}$ & $\mathrm{E}$ & - & - & + \\
\hline Sium medium Fisch. \& C. A. Mey. & $\mathrm{E}$ & - & - & + \\
\hline \multicolumn{5}{|l|}{ Verbenaceae } \\
\hline Phyla nodiflora (L.) Greene & $\mathrm{E}$ & + & - & - \\
\hline \multicolumn{5}{|l|}{ Zannichelliaceae } \\
\hline Zannichellia palustris L. & $\mathrm{S}$ & - & + & - \\
\hline
\end{tabular}

